\title{
Flood loss reduction of private households due to building precautionary measures - lessons learned from the Elbe flood in August 2002
}

\author{
H. Kreibich ${ }^{1}$, A. H. Thieken ${ }^{1}$, Th. Petrow ${ }^{1}$, M. Müller ${ }^{2}$, and B. Merz ${ }^{1}$ \\ ${ }^{1}$ GeoForschungsZentrum Potsdam (GFZ), Section Engineering Hydrology, Telegrafenberg, D-14473 Potsdam, Germany \\ ${ }^{2}$ Deutsche Rückversicherung AG, Hansaallee 177, D-40549 Düsseldorf, Germany
}

Received: 27 September 2004 - Revised: 20 December 2004 - Accepted: 27 December 2004 - Published: 25 January 2005

\begin{abstract}
Building houses in inundation areas is always a risk, since absolute flood protection is impossible. Where settlements already exist, flood damage must be kept as small as possible. Suitable means are precautionary measures such as elevated building configuration or flood adapted use. However, data about the effects of such measures are rare, and consequently, the efficiency of different precautionary measures is unclear. To improve the knowledge about efficient precautionary measures, approximately 1200 private households, which were affected by the 2002 flood at the river Elbe and its tributaries, were interviewed about the flood damage of their buildings and contents as well as about their precautionary measures. The affected households had little flood experience, i.e. only $15 \%$ had experienced a flood before. $59 \%$ of the households stated that they did not know, that they live in a flood prone area. Thus, people were not well prepared, e.g. just $11 \%$ had used and furnished their house in a flood adapted way and only $6 \%$ had a flood adapted building structure. Building precautionary measures are mainly effective in areas with frequent small floods. But also during the extreme flood event in 2002 building measures reduced the flood loss. From the six different building precautionary measures under study, flood adapted use and adapted interior fitting were the most effective ones. They reduced the damage ratio for buildings by $46 \%$ and $53 \%$, respectively. The damage ratio for contents was reduced by $48 \%$ due to flood adapted use and by $53 \%$ due to flood adapted interior fitting. The 2002 flood motivated a relatively large number of people to implement private precautionary measures, but still much more could be done. Hence, to further reduce flood losses, people's motivation to invest in precaution should be improved. More information campaigns and financial incentives should be issued to encourage precautionary measures.
\end{abstract}

Correspondence to: $\mathrm{H}$. Kreibich

(kreib@gfz-potsdam.de)

\section{Introduction}

The best strategy to avoid flood damage is certainly to avoid flood prone areas (Hooijer et al., 2004; Roy et al., 2003). Settling and accumulating values in inundation areas is always a risk, since absolute flood protection is impossible. Technical protection measures like dykes or flood retention basins can fail or be overtopped during extreme events. Where villages or towns already exist, flood damage must be kept as small as possible. Combined structural and non-structural flood mitigation plans seem most promising and are expected to result in significant economic benefit (Hayes, 2004). A non-structural option to reduce the remaining risk in the short term and for a sustained period of time are building precautionary measures (LAWA, 1995). It is believed that these measures are very effective especially in areas with frequent flood events and low flood water levels (ICPR, 2002), but data about their effects are rare. An exception is the report "Non Structural Flood Plain Management - Measures and their Effectiveness" by the International Commission for the Protection of the Rhine (ICPR, 2002). It evaluates the effectiveness of various measures depending on their capability to reduce the existent damage potential or the increase in damage potential and gives an idea of their importance concerning floods of different frequency and intensity. The damage reduction potential of various measures is given in absolute monetary values and in percentage classes. Unfortunately, it remains unclear on which data basis these estimates rely on. Thus, after the 2002 flood in Germany a survey was undertaken to improve the limited knowledge about damage mitigation measures. Although it is acknowledged that the prevention of damage to people (loss of life, adverse health effects) is most important, the present study is limited to the mitigation effects on direct monetary flood damage to residential building structure and contents.

The flood in August 2002, caused by the low-pressure system "Ilse", a Genoa Cyclone Type Vb weather system, had a disastrous impact, especially along the river Elbe and its tributaries. Extreme amounts of rainfall with maxima of $312 \mathrm{~mm}$ 
in $24 \mathrm{~h}$ and $406 \mathrm{~mm}$ in $72 \mathrm{~h}$ in Zinnwald-Georgenfeld, Germany caused an extreme flood event, e.g. with a return period of 150-200 years at the river Elbe at the gauge Dresden and with a return period of 200-300 years at the Mulde river at the gauge Erlln (IKSE, 2004). In Germany, the estimated costs amounted to at least 9.2 billion EUR, and 19 people were killed (BMI, 2002). Thus, the results from the 2002 flood in Saxony and Saxony-Anhalt show to which extent building precaution is able to mitigate damage even during an extreme event. The ideal or maximum possible damage reduction could not be reckoned, since at the high water levels which occurred during that event waterproof sealing and water barriers tend to be ineffective. In such extreme cases, low value and flood adapted use of the storeys in danger as well as adapted interior fitting, e.g. the use of water-proof material remain as the only effective precautionary measures (Egli, 2002).

However, this extreme event shows the importance of preparedness, which consists of preventive, precautionary and preparative measures. Prevention aims to avoid damage primarily by an appropriate land-use or structural measures, preparation tries to manage and cope with the catastrophe and precaution wants to mitigate damage mainly due to private flood proofing. Private risk reduction measures may be building precautionary measures or preparative measures like collecting information about flood protection, participating in neighbourly help or sign a flood insurance. In Germany, undertaking precautionary measures demands self dependent action by the potentially affected population. Only $14 \%$ of insurance companies reward voluntarily undertaken flood protection, mainly by providing cover despite of former flood damage if building retrofitting was undertaken (DKKV, 2003). But most crucial, there are no laws stipulating building precaution, all measures are voluntary (Heiland, 2002). Neither the state, the federal states, nor the communities are liable for flood damage to private contents, buildings or real estates. The often paid public financial aid is not based on legal commitment. Thus, potentially affected people should in any case undertake precautionary measures. However, people only act if they are aware of the flood risk and if they are informed about the possibility, effectiveness and cost of private precautionary measures (Grothmann and Reusswig, 2005). The socio-psychological survey of 157 residents of flood prone homes in Cologne undertaken by Grothmann and Reusswig (2005) showed, that for public risk communication it is important to address issues of concrete action and the social settings and environments that allow people to take their share of protection responsibility. Non-protective responses, like denial, wishful thinking and fatalism, as well as an unrealistic reliance on public flood protection need to be avoided. A case study including a detailed survey of 140 households, undertaken by Smith (1981), revealed, that in 1974 the city of Lismore in Australia was able to reduce its actual damage in the residential sector to $52.4 \%$ of the potential damage, since the community was well prepared due to frequent flooding and sufficient warning time. Lismore was affected by 14 floods since 1945, which had, for example, motivated the raise of $85 \%$ of the residential houses subsequent to construction. While this response in Lismore represents a large number of individual decisions taken with no coordination or subsidy from government (Smith, 1981), in recent years, agencies and other groups engaged in disaster mitigation have placed much emphasis on the objective of achieving disaster-resilient communities. Bruneau et al. (2003) developed a framework to quantitatively assess and enhance the seismic resilience of communities, where the technical, organizational, social and economic dimension of community resilience is taken into account. Another important aspect is the assessment of risk by the population, which is influenced by the following factors: perceived frequency and personal threat of floods, anxiety, expected probability of deaths and publicity of the flood risk (Plapp, 2003). Taking all these aspects into consideration, a coordinated effort is needed to improve the state of private precaution (OECD, 2004). In flood prone areas, where the last flood is long ago and in areas behind dykes and downstream of flood retention basins, where people rely on the technical flood protection it will be particularly difficult to motivate people to undertake precautionary measures, since there, no direct necessity is apparent. Thus, especially in these areas, flood hazard information has to be distributed and public relation should stimulate private precautionary measures. For this purpose, several German ministries and cities published information material (BMVBW, 2002; MURL, 2000; MUF, 1998; Stadt Köln, 1994). In the UK, various information material was published for example by the Environment Agency (Environment Agency, 2003a, b; Hampshire Flood Steering Group, 2002; SEPA, 2003), and in the USA information material was published e.g. by the Federal Emergency Management Agency (FEMA) as well as by the U.S. Army Corps of Engineers (USACE) (FEMA, 1998a, b, 1999; USACE, 1995, 1996). On the international level, for instance, the United Nations (UN) published "Guidelines for Reducing Flood Losses" (UN, 2002) and the UN Development Programme (UNDP) and the International Strategy for Disaster Reduction (ISDR) are developing a framework to encourage and spread appropriate and effective disaster risk reduction practices (WMO, 2004).

But as above-mentioned, quantitative information about the effects of private precautionary measures on damage reduction is scarce. Thus, 1248 affected private households in Saxony and Saxony-Anhalt were interviewed in the aftermath of the 2002 flood about the damage of their buildings and contents as well as about their precautionary measures. The purpose of this paper is to present the state of building precaution before and after the flood in 2002 and to identify effective precautionary measures and their damage mitigation effects during this extreme flood event. To use this information for the improvement of public preparedness, some of the results were included in a report that analysed the state of flood risk reduction in Germany in the light of the 2002 flood (DKKV, 2003). 


\section{Evasion:} elevated configuration and/or shielding with water barriers

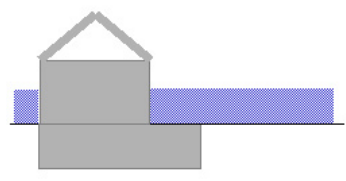

\section{Resisting: waterproof sealing and/or fortification of cellar and basis}

\section{Drawback:}

adapted use and/or interior fitting of the flood endangered storeys

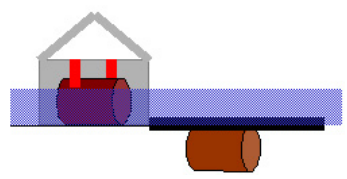

construction without a cellar, should be considered. In an area with frequent flooding in Australia, large numbers of wooden buildings were raised subsequent to construction (Smith, 1981). Although more difficult and expensive, this is also possible with masonry buildings (Sudbrack, 2003). Frame construction was historically well spread in Germany, presently masonry buildings are most common. In our survey, $69 \%$ of the buildings were masonry, $3 \%$ frame construction. Costs of subsequent raise do not only differ depending on the building type and method, but also from region to region. In the USA for instance, it was estimated, that it costs approximately $\$ 20350$ (16580 EUR) to elevate a $93 \mathrm{~m}^{2}$ large frame house with brick veneer walls for $1.2 \mathrm{~m}$ on continuous foundation walls (FEMA, 1998a). When undertaking this measure, the effect of soil saturation on basement walls and foundation, stability of natural slopes and scour potential should be considered (USACE, 1995).

Permanent or mobile water barriers can be used to keep flood water out of individual buildings or whole urban areas. In case of a flood warning some time is needed to set them up, depending on the system. If there is enough time, barriers made of sandbags can be constructed. Their efficiency depends on the number of rows and the duration of the flooding (Reeve and Badr, 2003). A profound description of alternatives to the non-reusable sandbags is published by Bowker (2002). Examples explicitly mentioned in our survey are watertight windows and door sealing, sandbags or local small flood protection walls.

Building a flood adapted house structure, e.g. using an es-

Fig. 1. Overview of different building precautionary strategies and measures (modified from ICPR, 2002).

\section{Review and definitions of building precautionary measures}

The following building precautionary measures may mitigate losses in flood prone areas (Fig. 1):

- elevated configuration,

- shielding with water barriers,

- waterproof sealing,

- fortification,

- flood adapted use,

- flood adapted interior fitting,

- safeguarding of hazardous substances.

In areas with a small probability of flood occurrence, building precautionary measures may have unfavourable benefitcost ratios (MURL, 2000). However, when extensive renewal or reconstruction is already in progress, precautionary building measures can often be implemented without large additional effort (FEMA, 1998b).

For buildings in flood prone areas an elevated configuration, e.g. building on stilts, walls, embankments, or a

pecially stable building foundation or waterproof seal the cellar, is generally quite expensive and can fail especially during extreme floods (MURL, 2000). However, steel frame and brick buildings tend to be less susceptible to collapse than other material, and waterproof drywall will hold up for long periods of inundation (USACE, 1996). Generally, the improvement of the stability of a building counters the damage caused by buoyancy, water pressure, erosion and washing out of free-standing elements. When groundwater rises above the foundation of the building, the walls and the basis of the building are subjected to buoyancy forces and water pressure. Counter measures that can be undertaken include anchoring the building or ensuring that the building itself is heavy enough. Only if the buoyancy forces surpass the effect of these measures, the building has to be flooded.

To prevent penetration of surface water and groundwater, any openings in the building must be raised or sealing measures must be implemented. Backwater valves stop the water from entering the building via sanitation in cases of backwater in the sewage network (DTLR, 2002). Buildings are sealed by using bitumen or strips of plastic (Environment Agency, 2003a) or by constructing the basis and walls of buildings out of concrete that is almost non-permeable (BMVBW, 2002). However, water should only be kept out of the buildings as long as they are stable. As a general rule, the maximum height of waterproofing should be approximately one meter above the ground, unless further structural building improvements were undertaken (Environment Agency, 


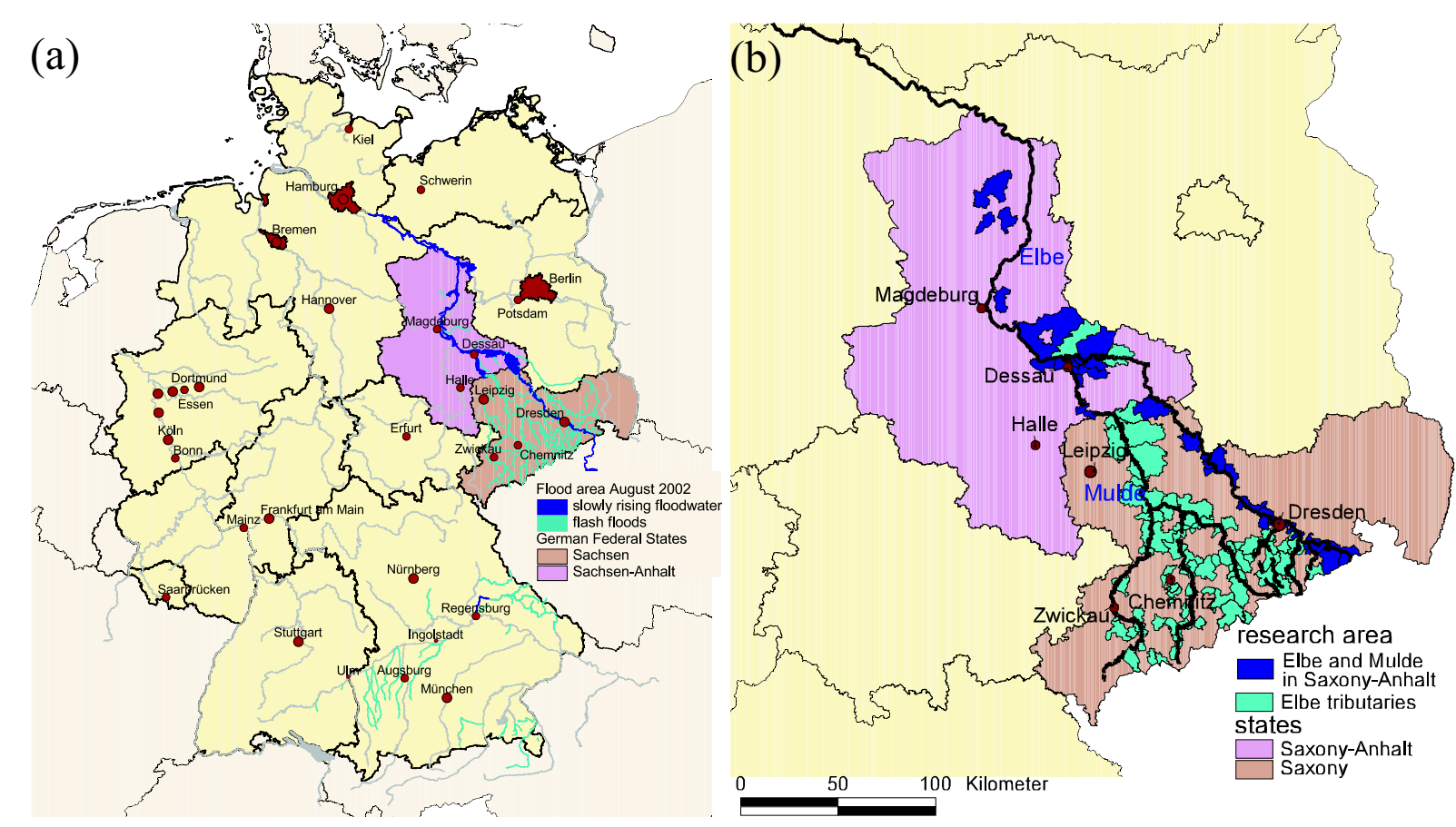

Fig. 2. (a) Overview of the 2002 flood in the federal states of Germany. (b) Structure of the research area; shown are the zip-code areas where completed interviews were undertaken.

2003b). For example, Kelman and Spence (2003) reported, that walls of unreinforced masonry buildings in the UK fail, when the flood depth differential between the inside and the outside is approximately $1.0-1.5 \mathrm{~m}$. If the water level continues to rise, the building must be flooded with clean water or the outside water must be allowed to ingress.

If the water cannot be prevented from entering the building, the damage can still be substantially reduced by flood adapted building use and interior fitting. Flood adapted building use means that cellars and endangered storeys are not used cost-intensively and no expensive upgrading is undertaken. For instance, installing a sauna or a high tech hobby room in the cellar should not be an option. Flood adapted interior fitting means, that in these storeys, only waterproofed building material and movable small interior decoration and furniture should be used (MURL, 2000). In contrast to carpeted floors, tiled floors would do much to reduce household losses (Yeo, 2002). Heating and other utilities like energy, gas and water supply installations should be moved to the upper storeys or designed in a flood-proofed way (FEMA, 1999).

Another important measure is the safe and secure storage of oil and other hazardous substances, e.g. in flood-proof fuel oil tanks (ICPR, 2002). Also small private sewage treatment plants must be protected against flooding. Tanks can float when the flood water level rises and can be damaged by water pressure. Containers must therefore be tested to ensure that they are secure against buoyancy, and all openings (ventilation fittings, filler plugs) must have water tight closures. Using gas- or district-heating avoids fuel oil contamination.

\section{Material and methods}

The flood in August 2002 in Saxony and Saxony-Anhalt comprised two types: first, flash floods affecting the tributary rivers especially in the Ore Mountains (Erzgebirge), including the headwaters of the river Mulde located in Saxony and second, the slowly rising river flood along the river Elbe and the down stream part of the river Mulde located in Saxony-Anhalt. To equally cover the areas with the different hydrological characteristics, the research area was divided into the area along the river Elbe in Saxony and SaxonyAnhalt as well as the river Mulde in Saxony-Anhalt on the one hand and the area along the Elbe tributaries on the other hand (Fig. 2). The intention was, that the combined analysis of the data covers a broad range of hydrological flood characteristics, so that local specifics are not too dominant and transferability to other regions eased.

With the help of official data, lists of all affected streets in these areas were comprised and a building specific random sample of households was generated. Computer-aided telephone interviews were undertaken with the VOXCO software package by the SOKO-Institute, Bielefeld. The standardised questionnaire comprised around 180 questions, and one interview lasted about $30 \mathrm{~min}$. Always the person with the best knowledge about the flood damage in a household was interviewed. Tenants were only asked about their household contents and the damage to it. To complete the interview the building owner was asked about the building and its damage. Building damage include all costs of repairing damage to the building structure, like plastering, replacing broken 
windows or repairing the heating system. Contents damage includes all costs for repairing or replacing of damaged contents, like domestic appliances, telephone and computer system, furniture or carpets. The detailed socio-scientific questionnaire, with questions not only about the total damage, but also about affected area per storey, estimated damage ratio, type and amount of the most expensive damage, kind and costs of all building repairs and all expensive affected domestic appliances etc. should ensure an information about the extent of damage as accurate as possible, hopefully avoiding a strategic response bias. The interviews were undertaken in April and May 2003. In total 1248 interviews were completed in Saxony and Saxony-Anhalt, 639 along the rivers Elbe and Mulde in Saxony-Anhalt and 609 along the Elbe tributaries.

Among other things, the questionnaire addressed the following topics:

a) precautionary measures:

- kind of measure (check list and additional open answers possible, multiple answers possible),

- time of realisation (check list: "undertaken before the flood", "after the flood", "planned within the next six months", "not intended"),

b) flood experience:

- number of experienced events (check list: "never", "once", "twice", "three times", "four times", "more than four times"),

- date of last experience flood event (open answers: month and year),

- knowledge about the flood hazard (yes or no),

c) contamination:

- kind of contamination (check list: "oil or petrol", "chemicals", "sewage or faeces", "no contamination" and additional open answers possible),

d) damage to building and contents:

- costs of all building repairs as replacement value (open answer),

- total contents damage as replacement value (open answer),

e) properties of the building and contents:

- number of storeys (check list: "only ground floor", "ground floor and 1 storey" up to "ground floor and more than 12 storeys"),

- type of the cellar (check list: "complete cellar", "partial cellar", "no cellar"),

- type of roof (check list: "flat roof", "living space in the attic", "no living space in the attic"),

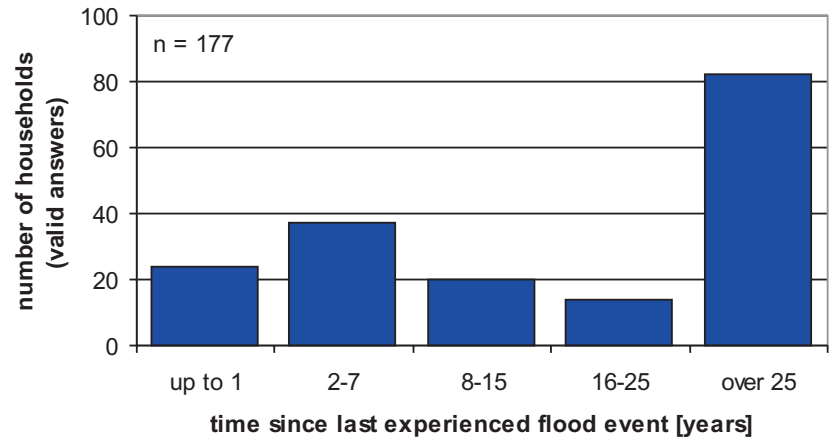

Fig. 3. Flood experience before August 2002, indicated by the time since the last experienced flood. 184 out of 1248 households (15\%) had experienced a flood before, of which 177 could remember the date.

- total living area (open answer).

A more detailed description of the whole questionnaire is published in Thieken et al. (2005) ${ }^{1}$. Answers concerning the living area, number of storeys, cellar- and roof-type were used to estimate the absolute values of buildings and contents according to insurance methods: The value of contents was assumed to be 600 EUR per $\mathrm{m}^{2}$ living area. The value of the building was calculated according to the VdS guideline 772 1988-10 (Dietz, 1999). Unfortunately not all interviews contained sufficient information to calculate the values and damage ratios. Building damage ratios could be calculated for 661 cases, contents damage ratios could be calculated for 972 cases. Although several real values will differ from the calculated ones, this approach seems reasonable due to the relatively large number of interviews. Damage reduction due to precautionary measures was assessed through the comparison of all actual damage cases where the specific measure was undertaken with all cases where the specific measure was not undertaken regardless of other measures.

This approach differs from the one applied by Smith (1981, 1994) who estimated the damage reduction due to early warning and flood experience via the comparison of actual and potential loss. Actual loss is estimated via damage surveys after a flood event. Potential loss is derived from synthetic stage-damage curves, representing worst case scenarios that make no allowance for actions to reduce flood losses. They do not rely on information from actual flood events but are based on hypothetical analyses by flood damage evaluators (Smith, 1994). However, such data was not available for the affected areas in Saxony and Saxony-Anhalt and additionally the uncertainty of such data is also unknown.

Statistical analysis was undertaken with the software SPSS for Windows, Version 11.5.1. Significant differences between two independent groups of data were tested by the Mann-Whitney-U-Test (damage ratios), for three groups of

\footnotetext{
${ }^{1}$ Thieken, A. H., Kreibich, H., Müller, M., and Merz, B.: Coping with floods: A survey among private households affected by the August 2002 flood in Germany, Hydro. Sci. J., submitted, 2005.
} 
Table 1. Selected parameters which are significantly different $(p<0.05)$ in the three subgroups of households: affected people, who had undertaken one or more building precautionary measures before the 2002 flood $(n=286)$, the ones who had undertaken one or more building precautionary measures after the 2002 flood $(n=509)$ and the ones who do not intend to undertake a building precautionary measure $(n=409)$. The investigated building precautionary measures are: adapted interior fitting, adapted use, purchase water barriers, improve stability and/or seal cellar and install heating or other utilities upstairs.

\begin{tabular}{|c|c|c|c|}
\hline & $\begin{array}{l}\text { Measure(s) } \\
\text { undertaken } \\
\text { before the } \\
2002 \text { flood }\end{array}$ & $\begin{array}{l}\text { Measure(s) } \\
\text { undertaken } \\
\text { after the } \\
2002 \text { flood }\end{array}$ & $\begin{array}{c}\text { No intention to } \\
\text { undertake } \\
\text { measure(s) }\end{array}$ \\
\hline Percentage of households with flood experience (\%) & 20 & 14 & 13 \\
\hline $\begin{array}{l}\text { Percentage of households who knew that they have been } \\
\text { living in a flood prone area }(\%)\end{array}$ & 51 & 36 & 39 \\
\hline $\begin{array}{l}\text { Percentage of households who believe in the effectiveness } \\
\text { of private precautionary measures }(\%)\end{array}$ & 41 & 39 & 27 \\
\hline Percentage of homeowners (\%) & 85 & 73 & 67 \\
\hline Mean number of household members & 2.9 & 2.8 & 2.5 \\
\hline Mean damage ratio of contents in $2002(\%)$ & 22 & 25 & 30 \\
\hline Mean damage ratio of buildings in $2002(\%)$ & 11 & 16 & 19 \\
\hline
\end{tabular}

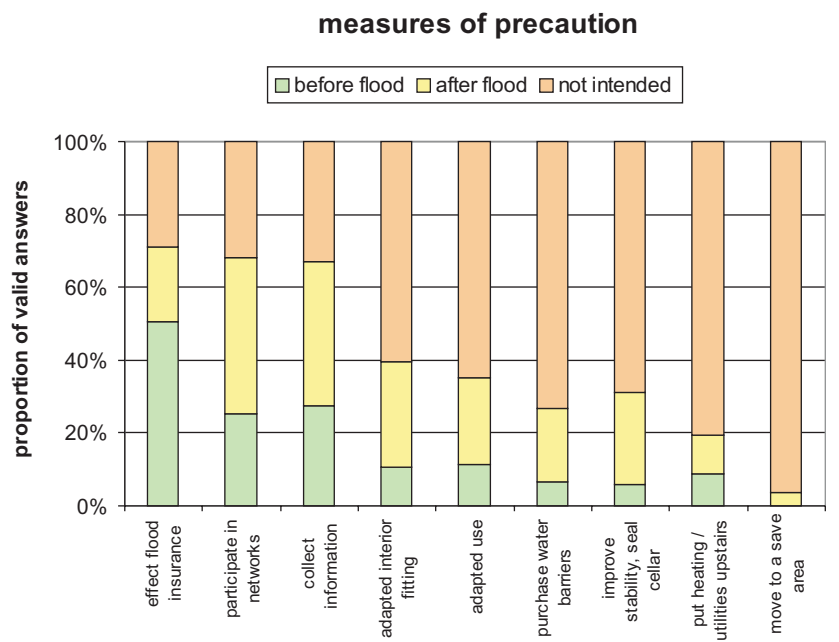

Fig. 4. Proportion of affected households, which undertook specific measure of precaution before, or after the flood 2002, or which do not intend to undertake the measure.

data (household parameters) the Kruskal-Wallis-H-Test was applied, both with a significance level of $p<0.05$.

\section{Results and discussion}

The people affected by the 2002 flood along the river Elbe and its tributaries had little flood experience. Only $15 \%$ of the households had experienced a flood before, along the river Elbe this share was even only $10 \%$. Furthermore, for the majority of the experienced people the remembrance had faded, since their last experience with a flood was more than 15 years ago (Fig. 3). For $46 \%$ of the households with flood experience the last flood was even more than 25 years ago and many households along the Elbe and in the Ore Mountains referred to the flood in 1974, when asked for the last experienced flood event. However, flood experience is a significant factor for flood loss mitigation (Table 1). The fact, that damage is effectively reduced where people have frequent and recent experience of floods, was also shown by Smith (1981) and Wind et al. (1999).

\subsection{State of building precaution before the flood in August} 2002

In general, people in the investigation area were not well prepared: just $11 \%$ had used and fitted their house interior in a flood adapted way, $9 \%$ had installed their heating and other utilities in higher storeys, $7 \%$ had water barriers available and only $6 \%$ had a flood adapted building structure, e.g. had an especially stable building foundation, or waterproof sealed cellar walls (Fig. 4). Besides flood experience, the knowledge to live in a flood prone area and the belief in the effectiveness of private precautionary measures seem to be decisive for undertaking precautionary measures (Table 1). Additionally, more homeowners in comparison with tenants had already acted before the flood (Table 1), a phenomenon which was also described by Grothmann and Reusswig (2005). Larger households seem to have more motivation to protect themselves. This result corresponds with Brenniman (1994) who found out, that one-person house- 

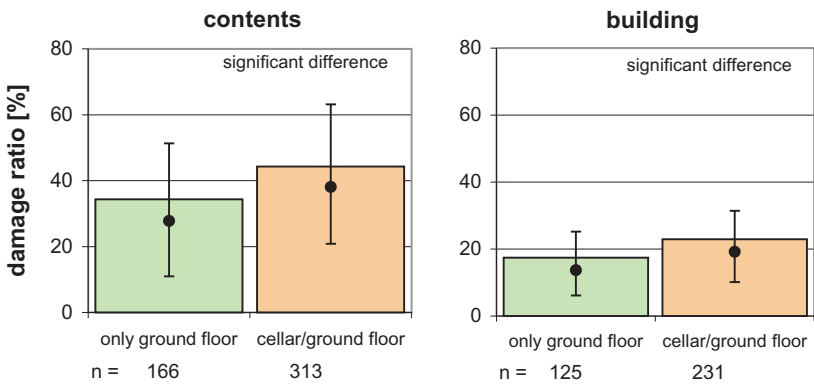

Fig. 5. Damage ratios of buildings with or without cellar damage (bars $=$ means, points $=$ medians and $25-75 \%$ percentiles).
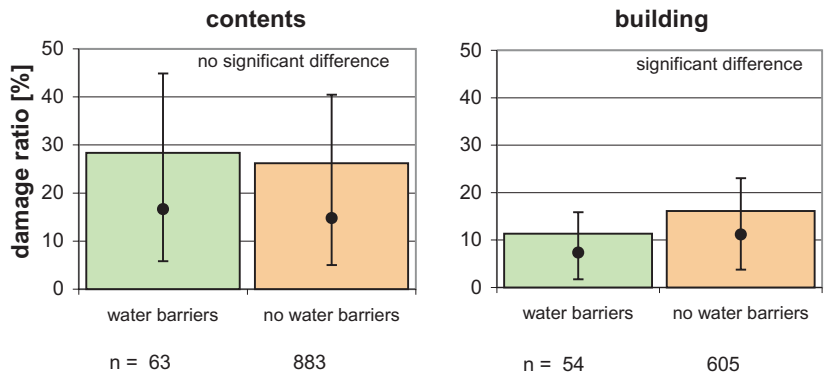

Fig. 6. The influence of available water barriers on the damage ratio (bars $=$ means, points $=$ medians and $25-75 \%$ percentiles).

holds spent the least amount of money on flood protection measures, while households with six or more people spent the most. Surprisingly, the household income as well as the time of building erection (age of the building) did not show significant differences among the households, which had undertaken building precautionary measures before the flood, after the flood or that did not intend to undertake measures.

Many households had participated in neighbourly help or flood networks (citizens' initiative for the improvement of flood preparedness and protection) and had collected information about flood protection before and during the flood, their proportion was $25 \%$ and $27 \%$, respectively.

$50 \%$ of the households were insured against flood losses, which is for historical reasons considerably more than the German average. According to information from the Federation of German Insurance Industry (Gesamtverband der Deutschen Versicherungswirtschaft - GDV) in the elementary damage sector there is currently an insurance density of approximately $10 \%$ for household contents and $4 \%$ for residential buildings in Germany. In the federal states in Eastern Germany the density of insurances against damage due to natural hazards is significantly higher, since flood losses were generally included in the household insurance in the former German Democratic Republic (GDR). And a lot of people in Eastern Germany still have comparable contracts.
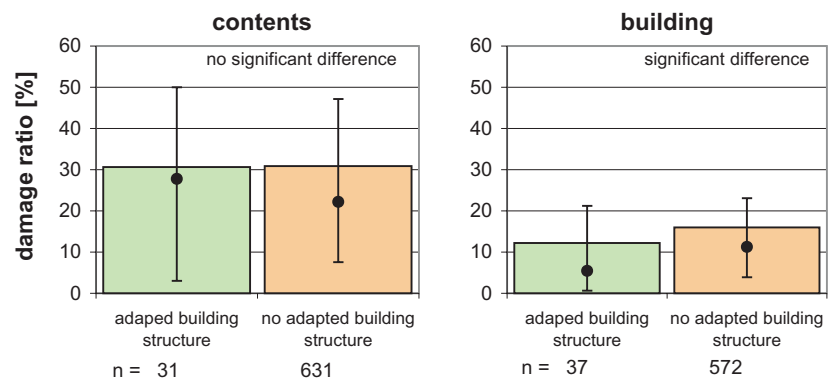

Fig. 7. The influence of flood adapted building structure on the damage ratio (bars=means, points $=$ medians and $25-75 \%$ percentiles)

\subsection{State of building precaution after the flood in August} 2002

The flood motivated a relatively large number of people to implement private risk reduction measures. Many learned their lesson and undertook precautionary measures in order to be better prepared for the next flood. For example, $43 \%$ joined flood networks and $40 \%$ collected information about private flood protection (Fig. 4).

However, elaborate precautionary building measures were accomplished by few people. For instance, after the flood only $20 \%$ of the households purchased water barriers and only $11 \%$ installed their heating and electrical utilities in higher storeys. The least considered measure is to move to a flood safe area (Fig. 4). In total, $42 \%$ of the people did undertake one or more building precautionary measure(s) after the flood. Again, homeowners and larger households were more motivated to act. But mainly, the belief of the households in the effectiveness of private precautionary measures seems to play a decisive role (Table 1). Surprisingly, the households estimate about the probability of being again affected by a flood in the future showed no significant difference. The fact, that households which do not intend to undertake building precautionary measures are the ones which had on average a higher damage than the ones which learned their lesson, might point to a kind of fatalism. $34 \%$ of the households do still not consider to undertake building precautionary measures. Thus, improved campaigns and financial incentives should be used to encourage private flood protection, which is especially cost-effective when implemented parallel to reconstruction after a flood.

\subsection{Damage mitigation effects of building precaution}

Measures of precaution are mainly effective in areas with frequent, small floods. But even during the extreme flood event in 2002 many precautionary building measures significantly reduced the flood loss.

Buildings without cellars are in general less affected by flooding and are less expensive to construct. Thus, buildings without cellars should be preferred in flood prone areas. In Saxony and Saxony-Anhalt $14 \%$ of the affected residential 

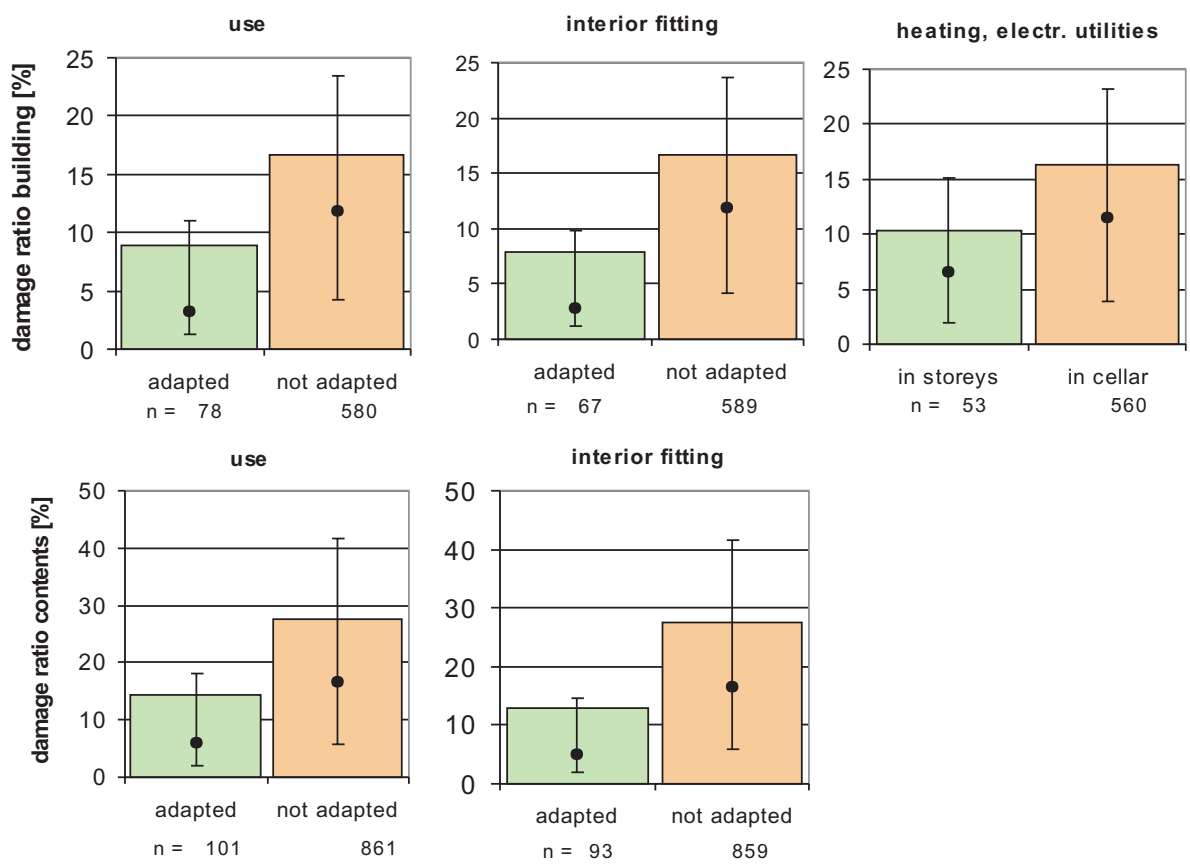

Fig. 8. Building and contents damage ratios for households who lived in buildings with and without flood adapted use, with and without flood adapted interior fitting and with the utilities in higher storeys or in the cellar (bars=means, points=medians and $25-75 \%$ percentiles).

buildings did not have a cellar. On average, the damage ratio for buildings (fraction of the flood damage in relation to the total building value) was $24 \%$ lower if only the ground floor was affected in comparison with additional cellar damage (Fig. 5). For contents, this difference in the damage ratios was $22 \%$. The ICPR (2002) states that building without cellar can reduce the flood loss in the residential sector by 3000 to 6000 EUR in Germany.

During the extreme flood event in 2002, many of the erected water barriers were overtopped and thus had no or only little effect. The private water barriers had on average no significant effect on the contents damage, i.e. the slightly higher damage ratio for contents if water barriers were available cannot be attributed to the precautionary measure (Fig. 6). For buildings, the mean damage ratio was reduced by $29 \%$ for the cases where water barriers were available. The ICPR (2002) states, that if the flood does not overflow the water barriers, a damage reduction of $60-80 \%$ is possible. The remaining loss depends mainly on the damage potential of cellars and whether or not cellar-walls are waterproof sealed (ICPR, 2002).

The limited effect of some precautionary measures during the extreme flood was also apparent for flood adapted building structure. River bed dislocations during the 2002 flood, for instance at the Müglitz river, led to the complete demolition of several buildings. Especially stable building foundation or waterproof sealed cellar walls had on average nearly no effect on contents damage, while the damage ratio for buildings was reduced by $24 \%$ (Fig. 7). However, another study shows that during less severe floods, such structural building measures have a significantly higher damage reduc- tion potential, although always dependent on the necessity of a cellar-flooding (ICPR, 2002).

When the inflow of water into the building cannot be prevented, a significant reduction of damage is still possible through flood adapted use, flood adapted interior fitting and utility installation in higher storeys. Our study shows, that these were the most effective measures during the extreme flood in 2002. Flood adapted use, adapted interior fitting as well as the installation of heating and electrical utilities in higher storeys reduced the mean damage ratios of buildings by $46 \%, 53 \%$ and $36 \%$, respectively (Fig. 8). The damage ratio for contents was reduced by $48 \%$ due to flood adapted use and by $53 \%$ due to flood adapted interior fitting. Expressed in absolute values, a mean damage reduction for contents of 9000 EUR and for buildings of 30000 EUR was achieved due to adapted use or adapted interior fitting. The installation of heating and other utilities in higher storeys could reduce the mean absolute damage by 24000 EUR (data not shown).

With $15 \%$, the amount of private oil central heating systems in the surveyed areas in Saxony and Saxony-Anhalt was relatively low, but still $44 \%$ of the households declared a pollution of their buildings and contents by oil or petrol. Oil contamination is not confined to the affected people's own buildings but may also cause damage to others. $41 \%$ of the households were affected by contamination with sewage, $19 \%$ with chemicals, whereas double or triple contaminations occurred. The different contaminations increased the mean damage ratios to contents and buildings significantly by $35-45 \%$ and by $47-52 \%$, respectively (Fig. 9). Generally, oil contamination may lead on average to a three times higher damage to buildings, in particular cases even to total 

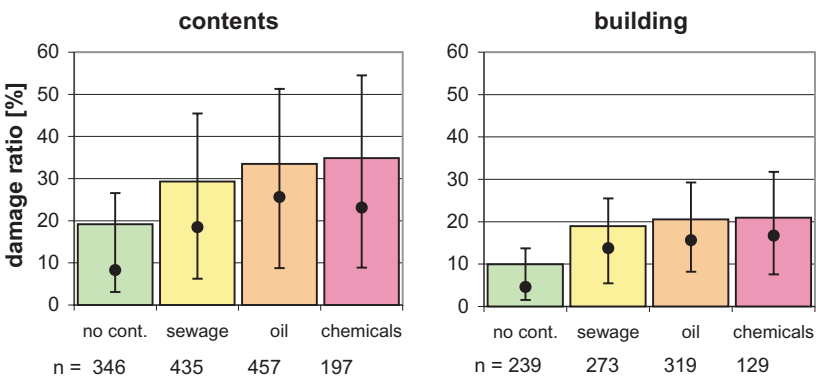

Fig. 9. Damage ratios related to contamination with different substances, whereas also double or triple contamination occurred (bars $=$ means, points $=$ medians and $25-75 \%$ percentiles).

loss (Egli, 2002). For example, during the "Pentecost Flood" in May 1999 in the south of Germany, in the region of Kelheim in Bavaria, the mean damage to buildings amounted to 15622 EUR, with additional oil contamination, the mean damage increased to 52886 EUR (Deutsche Rück, 1999).

Further research will be undertaken to be able to consider more than one factor (e.g. contamination type or precautionary measure) at a time. A multi-factorial damage estimation model will be developed on basis of the results of this survey.

\section{Conclusions}

Building precautionary measures have a significant potential to reduce flood damage of residential buildings and contents. Although these measures are mainly effective during small floods, they even led to significant mean damage reductions of up to $53 \%$ for buildings and contents during the extreme flood event in 2002. The flood motivated a relatively large number of people to implement private risk reduction measures. After the flood, one or more building precautionary measures were undertaken by $42 \%$ of the households. This motivation should further be stimulated with the help of information campaigns and financial incentives. Therewith, preparedness has to be kept over time.

Acknowledgements. The survey was undertaken within the German Research Network Natural Disasters (DFNK), in cooperation between the Section Engineering Hydrology at the GFZ Potsdam and the Deutsche Rückversicherung AG. We thank the Deutsche Rückversicherung AG and the German Ministry for Education and Research (BMBF) (No. 01SFR9969/5) for the financial support. Data Analysis was part of the interdisciplinary LessonsLearnedProcess initiated by the German Committee for disaster reduction (DKKV) after the flood in 2002, which was financed by the German Red Cross.

Edited by: M. Bostenaru

Reviewed by: two referees

\section{References}

BMI (Bundesministerium des Innern): Bundesregierung zieht vorläufige Schadensbilanz der Hochwasserkatastrophe: bisher finanzielle Hilfe im Umfang von über 700 Millionen Euro geleistet (Federal government draws provisional damage balance of the flood disaster: hitherto financial assistance provided to the extent of over 700 million EUR), Press release (6 November 2002), http://www.bmi.bund.de/dokumente/Pressemitteilung/ix 90912.htm, 2002.

BMVBW (Bundesministerium für Verkehr-, Bau- und Wohnungswesen): Hochwasserschutzfibel - Planen und Bauen von Gebäuden in hochwassergefährdeten Gebieten (Flood protection booklet - planning and constructing of buildings in floodendangered areas), BMVBW, Berlin, 2002.

Bowker, P.: Making properties more resistant to floods, P. I. Civ. E. M., 151, 3, 197-205, 2002.

Brenniman, G. R.: Flood damage in the upper des Plaines river basin of northeastern Illinois, The Environmental Professional, 16, 73-78, 1994.

Bruneau, M., Chang, S. E., Eguchi, R. T., Lee, G. C., O’Rourke, T. D., Reinhorn, A. M., Shinozuka, M., Tierney, K., Wallace, W. A., and von Winterfeldt, D.: A Framework to Quantitatively Assess and Enhance the Seismic Resilience of Communities, Earthquake Spectra, 19, 4, 733-752, 2003.

Deutsche Rück (Deutsche Rückversicherung AG): Das Pfingsthochwasser im Mai 1999 (The flood at Pentecost in May 1999), Deutsche Rück, Düsseldorf, 1999.

Dietz, H.: Wohngebäudeversicherung Kommentar (Commentary on insurance of residential buildings), 2nd edition, VVW Verlag Versicherungswirtschaft GmbH, Karlsruhe, 1999.

DKKV (Deutsches Komitee für Katastrophenvorsorge e.V.): Hochwasservorsorge in Deutschland - Lernen aus der Katastrophe 2002 im Elbegebiet (Flood risk reduction in Germany - Lessons Learned from the 2002 disaster in the Elbe region), Schriftenreihe des DKKV 29, DKKV, Bonn, 2003.

DTLR (Department for Transport, Local Government and the Regions): Preparing for floods - Interim guidance for improving the flood resistance of domestic and small business properties, DTLR, London, 2002.

Egli, T.: Hochwasserkatastrophe Ostdeutschland 2002 - Erkenntnisse in Bezug auf Gebäudeschäden, Bericht über die Abklärungsmission der Direktion für Entwicklung und Zusammenarbeit (DEZA, Abt. Humanitäre Hilfe und Schweizer Katastrophenhilfekorps) im Katastrophengebiet des Hochwassers der Elbe und ihrer Seitenflüsse vom 23-30 August 2002 (Flood disaster in eastern Germany 2002 - findings regarding building damage, report on the clarification mission of the authority for development and co-operation (DEZA, department humanitarian assistance and Swiss disaster relief corps) in the disaster area of the flood of the Elbe river and its tributaries of 23-30 August 2002), Vereinigung Kantonaler Feuerversicherungen, St. Gallen, 2002.

Environment Agency: Damage Limitation, How to make your home flood resistant, Bristol, 2003a.

Environment Agency: Flood Products. Using flood protection products - A guide for homeowners, Bristol, 2003b.

FEMA (Federal Emergency Management Agency): Homeowner's guide to retrofitting - Six ways to protect your house from flooding, FEMA Publications, Washington, DC, 1998a.

FEMA (Federal Emergency Management Agency): Repairing your flooded home, FEMA Publications, Washington, DC, 1998b. 
FEMA (Federal Emergency Management Agency): Protecting building utilities from flood damage - Principles and practices for the design and construction of flood resistant building utility systems, FEMA Publications, Washington, DC, 1999.

Grothmann, T. and Reusswig, F.: People at risk of flooding: Why some residents take precautionary action while others do not, Nat. Hazards, in press, 2005.

Hampshire Flood Steering Group: Managing flood risks in parishes - A best practice guide, $2^{\text {nd }}$ Edition, Environment Agency, Bristol, 2002.

Hayes, B. D.: Interdisciplinary planning of non-structural flood hazard mitigation, J. Water Res., 15-25, 2004.

Heiland, P.: Vorsorgender Hochwasserschutz durch Raumplanung, interregionale Kooperation und ökonomischen Lastenausgleich (Precautionary flood protection by spatial planning, interregional co-operation and economic distribution of burdens), Schriftenreihe WAR 143, Technische Universität Darmstadt, Darmstadt, 2002.

Hooijer, A., Klijn, F., Pedroli, G. B. M., and Van Os, A. G.: Towards sustainable flood risk management in the Rhine and Meuse river basins: Synopsis of the findings of IRMA-SPONGE, River Res. Applic., 20, 343-357, 2004.

ICPR (International Commission for the Protection of the Rhine): Non Structural Flood Plain Management - Measures and their Effectiveness, ICPR, Koblenz, 2002.

IKSE (Internationale Kommission zum Schutz der Elbe): Dokumentation des Hochwassers vom August 2002 im Einzugsgebiet der Elbe (Documentation of the flood in August 2002 in the Elbe catchment), IKSE, Magdeburg, 2004.

Kelman, I. and Spence, R.: A Limit Analysis of Unreinforced Masonry Failing Under Flood Water Pressures, Masonry International, 16, 2, 51-61, 2003.

LAWA (Länderarbeitsgemeinschaft Wasser): Leitlinien für einen zukunftsweisenden Hochwasserschutz - Hochwasser - Ursachen und Konsequenzen (Guidelines for a trend-setting flood protection - floods - causes and consequences), Länderarbeitsgemeinschaft Wasser, Stuttgart, 1995.

MUF (Ministerium für Umwelt und Forsten Rheinland-Pfalz): Hochwasserhandbuch - Leben, Wohnen und Bauen in hochwassergefährdeten Gebieten des Ministeriums für Umwelt und Forsten Rheinland-Pfalz (Flood manual - living and building in flood-endangered areas of the Ministry for environment and forests Rhineland-Palatinate), MUF, Mainz, 1998.

MURL (Ministerium für Umwelt, Raumordnung und Landwirtschaft des Landes Nordrhein-Westfalen): Hochwasserfibel Bauvorsorge in hochwassergefährdeten Gebieten (Flood booklet - building precaution in flood-endangered areas), MURL, Düsseldorf, 2000.
OECD (Organisation for economic co-operation and development) Large-scale disasters - lessons learned, OECD Publications Service, Paris, 2004.

Plapp, S. T.: Wahrnehmung von Risiken aus Naturkatastrophen Eine empirische Untersuchung in sechs gefährdeten Gebieten Süd- und Westdeutschlands (Risk perception of natural catastrophes - an empirical investigation in six endangers areas in south and west Germany), Karlsruher Reihe II - Risikoforschung und Versicherungsmanagement, Karlsruhe, 2003.

Reeve, D. and Badr, A.: Performance of sandbags for domestic flood defence, P. I. Civ. E. W., 156, 4, 341-349, 2003.

Roy, E., Rousselle, J., and Lacroix, J.: Flood Damage Reduction Program (FDRP) in Québec : Case Study of the Chaudière River, Nat. Hazards, 28, 387-405, 2003.

SEPA (Scottish Environment Protection Agency): Flood alleviation products. Stirling, 2003.

Smith, D. I.: Actual and potential flood damage: a case study for urban Lismore, NSW, Australia, Appl. Geography, 1, 31-39, 1981.

Smith, D. I.: Flood damage estimation - A review of urban stagedamage curves and loss functions, Water SA, 20, 3, 231-238, 1994.

Stadt Köln: Hochwasser-Merkblatt für Bewohner gefährdeter Gebiete der Stadt Köln (Flood instruction card for inhabitants of endangered areas in the city of Cologne), Köln, 1994.

Sudbrack, B. K.: Einfach anheben - Wertschöpfung in Hochwassergebieten durch Hausanhebungen (Simply raise - creation of value in flood areas by house rising), Deutsches IngenieurBlatt, 11, 23, 2003.

UN (United Nations): Guidelines for Reducing Flood Losses, http: //www.unisdr.org, 2002.

USACE (U.S. Army Corps of Engineers): Flood Proofing, Washington, DC, EP 1165-2-314, 1995.

USACE (U.S. Army Corps of Engineers): Engineering and Design Risk-Based analysis for flood damage reduction studies, Washington, DC, Manual No. 1110-2-1619, 1996.

VdS 772 (Verband der Sachversicherer e.V., today: Gesamtverband der Deutschen Versicherungswirtschaft e.V.): Ermittlung der Versicherungssumme 1914 für Wohngebäude nach Wohnfläche und Ausstattungsmerkmalen (Determination of the insured sum 1914 for residential buildings according to floor space and equipment characteristics), 1988-10, Köln, 1988.

Wind, H. G., Nierop, T. M., de Blois, C .J., and de Kok, J. L.: Analysis of flood damages from the 1993 and 1995 Meuse floods, Water Res. R., 35, 11, 3459-3465, 1999.

WMO (World Meteorological Organisation): Water and disasters Be informed and be prepared, WMO-No. 971, Geneva, 2004.

Yeo, S. W.: Flooding in Australia: A review of events in 1998, Nat. Hazards, 25, 177-191, 2002. 